Article

\title{
Occurrence and Molecular Characteristics of Mcr-1-Positive Escherichia coli from Healthy Meat Ducks in Shandong Province of China
}

\author{
Fengzhi Liu ${ }^{1,2}$, Ruihua Zhang ${ }^{1,2}$, Yupeng Yang ${ }^{1,2}$, Hanqing $\mathrm{Li}^{1,2}$, Jingyu Wang ${ }^{1,2}$, \\ Jingjing Lan ${ }^{1,2}$, Pengfei Li ${ }^{1}$, Yanli Zhu ${ }^{1,2}$, Zhijing Xie ${ }^{1,2}$ and Shijin Jiang ${ }^{1,2, *(D)}$ \\ 1 College of Veterinary Medicine, Shandong Agricultural University, Taian 271000, China; \\ lfz156@163.com (F.L.); ruirui041127@126.com (R.Z.); 18865485081@163.com (Y.Y.); \\ lihqnqing13146@163.com (H.L.); jywang676@163.com (J.W.); jjlan1024@163.com (J.L.); \\ p.li@erasmusmc.nl (P.L.); ylz@sdau.edu.cn (Y.Z.); xiezhj@sdau.edu.cn (Z.X.) \\ 2 Shandong Provincial Key Laboratory of Animal Biotechnology and Disease Control and Prevention, \\ Taian 271000, China \\ * Correspondence: sjjiang@sdau.edu.cn; Tel.: +86-538-8245799
}

Received: 1 April 2020; Accepted: 24 July 2020; Published: 29 July 2020

Simple Summary: Colistin has been used as a growth promotant in livestock feed for many years. To date, there are few reports about the prevalence and molecular characteristics of fecal Escherichia coli bearing $\mathrm{mcr}-1$ in the meat ducks. In this study, among 120 fecal Escherichia coli strains isolated from healthy meat ducks, a total of nine mcr-1-containing E. coli strains were identified and two were identified as extra-intestinal pathogenic E. coli. The 9 mcr-1-bearing E. coli isolates were clonally unrelated, carried two different genetic contexts of $m c r-1$, and the colistin-resistant phenotype of them was successfully transferred to the recipient strains. These results highlight that healthy meat duck is a potential reservoir for multidrug resistant $m c r-1$-containing E. coli strains.

\begin{abstract}
Colistin has been used as a growth promotant in livestock feed for many years. In China, mcr-1-positive Escherichia coli strains have been isolated from humans, chickens, and pigs. To date, there are few reports about the prevalence and molecular characteristics of fecal E. coli bearing $m c r-1$ in the meat ducks. In this study, the prevalence of $m c r-1$ gene was investigated among 120 fecal E. coli strains isolated from healthy meat ducks in Shandong province of China between October 2017 and February 2018. A total of nine $m c r-1$-containing E. coli strains were identified and two were identified as extra-intestinal pathogenic E. coli (ExPEC) among them. The clonal relationship of the nine E. coli strains was determined by multilocus sequencing typing (MLST) and pulsed field gel electrophoresis (PFGE), and the results indicated that all $m c r$-1-carrying isolates were clonally unrelated. Two different genetic contexts of $m c r-1$ were identified among these isolates. Colistin-resistant phenotype of all the isolates was successfully transferred to the recipient strains by conjugation experiments and seven transconjugants carried a single plasmid. The $m c r-1$ was located on three replicon plasmids: IncI2 $(\mathrm{n}=4)$, IncFII $(\mathrm{n}=2)$ and $\operatorname{IncN}(\mathrm{n}=1)$. Complete sequence analysis of a representative plasmid pTA9 revealed that it was strikingly similar with plasmid pMCR1-IncI2 of E. coli, plasmid pHNSHP45 of E. coli, and plasmid pWF-5-19C of Cronobacter sakazakii, implying that pTA9-like plasmids may be epidemic plasmids that mediate the spread of mcr-1 among Enterobacteriaceae. These results highlight that healthy meat duck is a potential reservoir for multidrug resistant $\mathrm{mcr}$-1-containing E. coli strains.
\end{abstract}

Keywords: fecal Escherichia coli; mcr-1; plasmid; healthy meat duck 


\section{Introduction}

Avian pathogenic Escherichia coli (APEC), a subgroup of extra-intestinal pathogenic E. coli (ExPEC), can cause severe disease characterized by perihepatitis, pericarditis, and airsacculitis, which results in economic and welfare costs in the poultry industry worldwide [1]. There are similar virulence genes between APEC strains and the ExPEC strains in humans [2]. Via the food chain, the multidrug resistant (MDR) APEC strains can transfer from poultry to man, which not only increases the difficulty of treating animal diseases, but also poses a serious threat to human health [3].

As a polymyxin antibacterial agent, colistin is considered as the last-resort drug with excellent bactericidal activity against multidrug-resistant Gram-negative pathogens in humans [4]. However, the recent emergence of $m c r$-like genes ( $m c r-1$ to $m c r-10)$ potentially threatens the clinical effectiveness of colistin [5-7]. These $\mathrm{mcr}$ genes have been disseminated to more than 40 countries across at least five continents in multiple ecosystems and traced to more than 11 bacterial species $[8,9]$. The worldwide distribution of $m c r-1$ gene strongly indicates a potential food-chain-based spread route [10]. Many studies showed that the prevalent dissemination of the $m c r-1$ gene relied on transfer by conjugative plasmids such as pHNSHP45, pECJS-B65-33, and pECJS-61-63 [8,9,11].

The intestinal flora of the food animals and humans is a reservoir for antibiotic resistance genes, and the resistant genes can spread from food animals to humans by commensal flora [12,13]. In China, mcr-1-positive E. coli strains have been isolated from humans, chickens, and pigs [14]. To date, prevalence and molecular characteristics of many viral and bacterial pathogens has been identified in Chinese duck flocks [15-21], but there are few reports about the prevalence and molecular characteristics of fecal E. coli bearing $m c r-1$ from the meat ducks [22-24]. In this study, we isolated E. coli strains from the feces of healthy meat ducks in Shandong province of China, and investigated the occurrence and molecular characteristics of the mcr-1-positive E. coli strains.

\section{Materials and Methods}

\subsection{Bacterial Isolate}

From October 2017 to February 2018, a total of 120 cloacal swabs were collected from healthy meat ducks from 12 duck farms in Shandong province, China. The cloacal swabs were immediately put into Luria-Bertani (LB) broth and incubated for $24 \mathrm{~h}$ at $37^{\circ} \mathrm{C}$. All samples were seeded on selective MacConkey agar plates. Bright pink, round, and smooth surface E. coli colonies were picked on selective plates for further analysis. The $E$. coli isolates were identified through $16 \mathrm{~S}$ rDNA sequence analysis, and the $16 \mathrm{~S}$ rDNA primers were designed in this study (Table 1).

Table 1. The primers used in this study.

\begin{tabular}{cccc}
\hline Detected Genes & Primer Sequence $\left(\mathbf{5}^{\prime}-\mathbf{3}^{\prime}\right)$ & Size/Bp \\
\hline 16S rDNA & rmtB & $\begin{array}{c}\text { agagtttgatcctggctcag } \\
\text { ggttaccttgttacgactt }\end{array}$ & 1505 \\
\hline Resistance gene & atgaacatcaacgatgccctc & 756 \\
ttatccattctttttatcaagtatat & nikB & $\begin{array}{c}\text { gatgaacttgatcatcgtgttgt } \\
\text { gtaattctgacgaaaaagacga }\end{array}$ & 705 \\
\cline { 2 - 4 } Genetic context of the $m c r-1$ gene & top & $\begin{array}{c}\text { gagttcgcaccgctgacagac } \\
\text { atcaaacaccgacttcagggcatc }\end{array}$ & 330 \\
\hline
\end{tabular}

\subsection{Antimicrobial Susceptibility Testing}

The minimum inhibitory concentrations (MICs) of tetracycline, fosfomycin, colistin, gentamicin, imipenem, ciprofloxacin, cefotaxime, amikacin, and florfenicol for the E. coli isolates picked on the plates and transconjugants were tested by the broth dilution method and interpreted according to 
the Clinical and Laboratory Standards Institute $[25,26]$. The colistin breakpoint ( $\geq 2 \mu \mathrm{g} / \mathrm{mL})$ was used according to the European Committee on Antimicrobial Susceptibility Testing guidelines [27]. E. coli ATCC 25,922 was used as the quality-control strain.

\subsection{Molecular Detection}

All colistin resistant E. coli strains and their transconjugants were screened for $m c r-1$ gene by polymerase chain reaction (PCR) assays [14]. According to the surrounding structure of pTA9, the primers of nikB and top gene were designed to determine the genetic environment of the mor- 1 gene (Table 1). The resistance genes (floR, tet $(\mathrm{A}), \beta$-Lactamase, $r m t B$, and $f o s A 3)$ and virulence-associated genes were analyzed for the mor-1-containing E. coli strains and their transconjugants by PCR (Table S1) [28-31]. The strains were classified as ExPEC if they carried at least two of five key virulence genes: papA and/or papC (pyelonephritis-associated pili A/C, counted as 1: P fimbriae), sfa/foc (S/F1C fimbriae), afa/dra (Afimbrial/Dr-binding adhesins), iutA (aerobactin system), and kpsM II (group 2 capsules) [32].

\subsection{Molecular Typing}

XbaI-PFGE was performed as described previously [33] using the CHEF-MAPPER System (Bio-Rad Laboratories, Hercules, CA, USA). Phylogenetic analysis of PFGE patterns was performed using the PyElph software version 1.4 [34]. The UPGMA method was used for clustering. Mcr-1-positive strains were studied by multilocus sequence typing (MLST) as previously described [35]. Phylogenetic classification was performed using a triplex PCR reaction [36].

\subsection{Conjugation Assays}

Conjugation experiments were performed using azide resistant E. coli J53 as the recipient [37]. Transconjugants were selected on agar containing $200 \mathrm{mg} / \mathrm{L}$ azide and $2 \mathrm{mg} / \mathrm{L}$ colistin and confirmed by enterobacterial repetitive intergenic consensus (ERIC)-PCR method [38].

\subsection{Plasmid Characterization}

Mcr-1-containing plasmids were sized by the S1 nuclease pulsed field gel electrophoresis (S1-PFGE) [33]. A single plasmid carried by transconjugants was used for plasmid analysis. The replicon types of plasmids were determined by PCR-based replicon typing (PBRT) [39]. A representative mcr-1-harboring plasmid, pTA9, was extracted using the Qiagen Large Construct kit (Qiagen, Hilden, Germany) and sequenced using the Illumina MisSeq system using prepared paired-end $2 \times 300 \mathrm{bp}$ libraries. The coverage of the plasmid is $200 \times$. Raw data was assembled using the SPAdes Genome Assembler (http://cab.spbu.ru/software/spades/) and SSPACE (version 3.0). Gap was closed with PCR and Sanger sequencing. The plasmid was annotated using the RAST tool (http://rast.nmpdr.org/).

\subsection{Ethics Statement}

All animal experiments were carried out in accordance with guidelines issued by the Shandong Agricultural University Animal Care and Use Committee (approval number, SDAUA-2017-043).

\section{Results and Discussion}

\subsection{Identification of Mcr-1-Carrying E. coli Isolates}

In this study, a total of 120 fecal E. coli strains were isolated from healthy meat ducks from October 2017 to February 2018. Among them, only nine isolates $(7.5 \%, 9 / 120)$ were resistant to colistin and identified as positive for $m c r-1$ gene by PCR amplification and sequencing. In China, high $m c r-1$ gene carriage rates (about 15\% to 30\%) were observed in E. coli isolates collected from poultry and pigs between 2011 to 2016 [14,40,41]. Colistin had been commonly used as a growth promotant in livestock feed for many years and had been banned from April 2017 in China. However, the samples in the 
above-mentioned studies were collected before the ban was issued $[14,40,41]$. The samples in this study were collected after the ban was issued. So, we speculated that the ban of colistin in animal feed might be the main reason why the low frequency of $m c r-1$ gene was found in fecal E. coli isolates in this study.

\subsection{Antimicrobial Resistance Patterns and Resistance Genes}

In this study, all of the $9 \mathrm{mcr}$-1-bearing E. coli isolates were MDR strains (resistance to antibiotics of at least three classes). Among them, 9, 8, 8, and 7 isolates were resistant to tetracycline, cefotaxime, ciprofloxacin, and florfenicol respectively, but all were susceptible to imipenem (Table 2). Mcr-1 is usually found to coexist with other resistance genes (extended-spectrum $\beta$-lactam, floR, and tet(A)) in bacteria [42-44]. In this study, 6, 5, 5, and 2 of the nine $m c r-1$-bearing E. coli isolates harbored floR, $b l a_{\mathrm{CTX}-\mathrm{M}}, b l a_{\mathrm{TEM}-1}$, and tet(A) genes, respectively (Table 2). The association with other resistance genes is likely to favor the dissemination of $m c r-1$ by co-selection, since cephalosporins, florfenicol, and tetracycline are used extensively in animal husbandry in China.

Table 2. Molecular characteristics of the $9 \mathrm{mcr}$-1-positive E. coli strains isolated from healthy meat ducks in this study.

\begin{tabular}{|c|c|c|c|c|c|c|}
\hline Strains & Farm & MLST & Groups & Virulence Genes & Resistance Genes & Resistant Pattern \\
\hline TA9* & 1 & ST457 & A & iut $A$, papC & floR, fos A3 & CL/CIP/TET/FFC/FOS ${ }^{1}$ \\
\hline TA15 & 2 & ST69 & A & iutA & $b l a_{\mathrm{TEM}-1}$, fos $A 3$ & CL/CTX/CIP/TET/FOS/AK \\
\hline TA32 & 3 & ST469 & B1 & iut $A$ & $b l a_{\mathrm{CTX}-\mathrm{M}-55,}, r m t B$ & CL/CTX/CIP/TET/AK \\
\hline TA59 & 6 & ST10 & A & papC & $b^{b l a}{ }_{\mathrm{CTX}-\mathrm{M}-55}$, floR, tet(A) & CL/CTX/TET/FFC/AK/GN \\
\hline TA78 & 8 & ST354 & A & papA & $b l a \mathrm{TEM}-1$, floR, tet(A) & CL/CTX/CIP/TET/FFC/GN \\
\hline TA114 & 12 & ST410 & A & iut $A$ & $b l a_{\mathrm{CTX}-\mathrm{M}-55}, b l a_{\mathrm{TEM}-1}$, floR, rmtB & CL/CTX/CIP/TET/FFC/AK \\
\hline
\end{tabular}

${ }^{*}$ The ExPEC strains. ${ }^{1} \mathrm{CL}$, colistin; FOS, fosfomycin; TET, tetracycline; FFC, florfenicol; CTX, cefotaxime; GN, gentamicin; CIP, ciprofloxacin; AK, amikacin.

\subsection{Phylogenetic Groups and Virulence Genes}

All of the nine $m c r-1$-bearing E. coli isolates contained virulence genes, and the iutA (aerobactin acquisition) gene was identified in 6 ones (Table 2). Two of the nine E. coli isolates, namely TA9 and TA103 carrying both iutA and papC genes were identified as ExPEC according to the standard [32] (Table 2). The presence of $m c r$-1-harboring ExPEC isolates in healthy meat ducks posed a serious health threat to consumers. Fortunately, no virulence gene was co-transferred with $m c r-1$ gene to the recipient (Table 3). To the best of our knowledge, this is the first report about mcr-1-positive ExPEC isolates identified from healthy meat animals.

Table 3. Characterization of some plasmids carrying mcr-1 of transconjugants.

\begin{tabular}{|c|c|c|c|c|c|c|c|}
\hline \multirow[b]{2}{*}{ Strains } & \multirow{2}{*}{$\begin{array}{c}\text { Co-Transfer of } \\
\text { Other Resistance } \\
\text { Gene }\end{array}$} & \multirow{2}{*}{$\begin{array}{c}\text { Co-Transfer } \\
\text { of Virulence } \\
\text { Gene }\end{array}$} & \multirow{2}{*}{$\begin{array}{l}\text { Resistant } \\
\text { Patterns }\end{array}$} & \multirow{2}{*}{$\begin{array}{c}\text { Contest of } \\
\text { Mcr-1 }\end{array}$} & \multirow{2}{*}{$\begin{array}{l}\text { Conjugation } \\
\text { Efficiency }\end{array}$} & \multicolumn{2}{|c|}{ Mcr-1-Carrying Plasmids } \\
\hline & & & & & & Size $(\mathbf{k b})$ & $\begin{array}{l}\text { Replicon } \\
\text { Type }\end{array}$ \\
\hline TA15 & 1 & / & $\mathrm{CL}$ & I & $6.64 \times 10^{-4}$ & $\approx 65$ & $\mathrm{I} 2$ \\
\hline TA20 & 1 & / & $\mathrm{CL}$ & II & $7.56 \times 10^{-2}$ & $\approx 65$ & $\mathrm{I} 2$ \\
\hline TA32 & 1 & / & $\mathrm{CL}$ & I & $2.17 \times 10^{-3}$ & $\approx 65$ & I2 \\
\hline TA78 & / & / & $\mathrm{CL}$ & I & $1.85 \times 10^{-5}$ & $\approx 95$ & $\mathrm{~N}$ \\
\hline TA95 & l & / & $\mathrm{CL}$ & I & $9.93 \times 10^{-5}$ & $\approx 102$ & FII \\
\hline TA103 * & bla $a_{\mathrm{CTX}-\mathrm{M}-55}$, floR & / & CL/CTX/FFC & II & $4.35 \times 10^{-7}$ & / & / \\
\hline TA114 & floR & 1 & $\mathrm{CL} / \mathrm{FFC}$ & I & $3.19 \times 10^{-6}$ & 1 & i \\
\hline
\end{tabular}

* The ExPEC strains. ${ }^{1} \mathrm{CL}$, colistin; CTX, cefotaxime; FFC, florfenicol. 
Phylogenetic group analysis revealed that seven $(77.8 \%)$ of the nine $m c r-1$-bearing E. coli isolates belonged to group A and the other two isolates were classed into group D and B1, respectively (Table 2). Similar results were found in the fecal E. coli isolates from chickens in Australia, which were classed into group A, D, B1, and B2, and group A was dominant [45]. The two ExPEC isolates (TA9 and TA103) respectively belonged to groups $\mathrm{A}$ and $\mathrm{D}$, which was similar to the result that ExPEC isolates from retail chicken meat products and eggs belonged mainly to group A and D [46].

\subsection{Molecular Typing}

Based on XbaI-PFGE analysis, we found that the nine $m c r$-1-bearing E. coli isolates were highly diverse (Figure 1). These data suggested that the spread of $m c r-1$ gene among E. coli isolates was not due to clonally expansion. MLST analysis result showed that the nine $\mathrm{mcr}$-1-bearing E. coli isolates belonged to nine STs: ST457, ST69, ST2973, ST469, ST10, ST354, ST3170, ST345, and ST410 (Table 2), which also revealed the high genetic diversity among the nine $m c r-1$-bearing $E$. coli isolates. As the most common mcr-1-containing E. coli, ST10 was often found in China [47,48]. The E. coli ST410 was widely disseminated in the environment, food animals, humans, and wildlife [49]. The high genetic diversity of the mcr-1-bearing E. coli isolates in this study indicates that the molecular type of E. coli isolates from healthy meat ducks is very complicated.

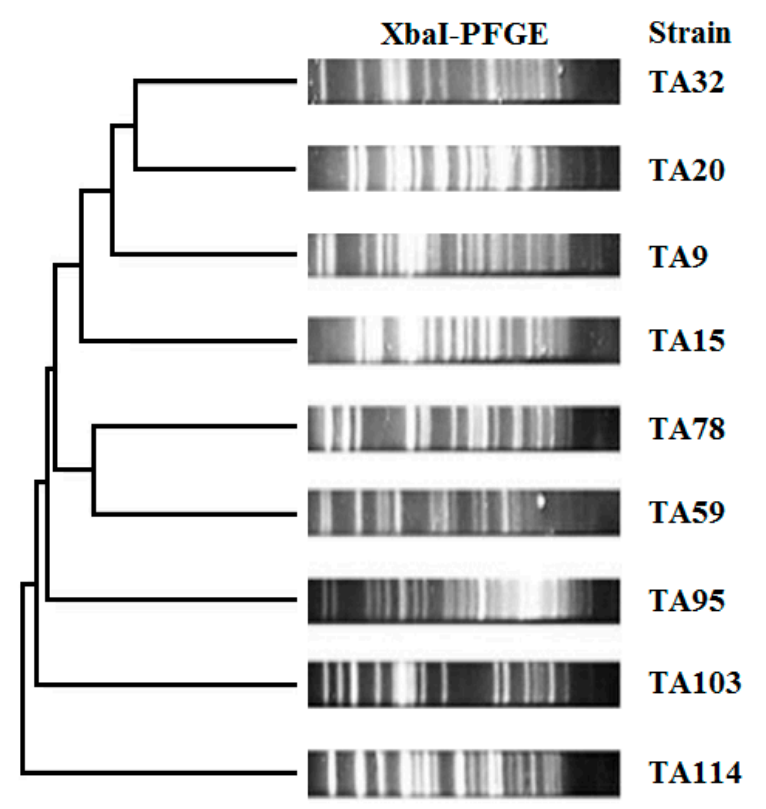

Figure 1. XbaI-PFGE dendrograms showing the genetic relationships of the 9 mcr-1-positive E. coli strains isolated in this study.

\subsection{Genetic Environment of Mcr-1 Gene}

Two different genetic contexts of $m c r-1$ ( 0 or 1 copy of ISApl1 was present beside $m c r-1$ ) were identified among the nine $m c r-1$ positive E. coli strains (Figure 2 and Table 3). The type I genetic context of $m c r-1$ (one copy of ISApl1 was present beside $m c r-1$ ) was identified in seven $m c r$-1-containing E. coli isolates. The type II genetic context of $m c r-1$ (ISApI1 was absent) was found in two $m c r-1$-bearing E. coli strains. All mcr-1 positive E. coli strains included the conserved mcr-1-pap2 segment, which might be horizontally transferred into various plasmids [50]. An ISApl1 element was located upstream of the $m c r-1$ gene on seven $m c r-1$-positive isolates. The absence of ISApl1 in $m c r$-1-bearing plasmids could be explained by the mobilization of an ISApl1 composite transposon to conjugative plasmids, which subsequently lost ISApl1 copies [51]. 


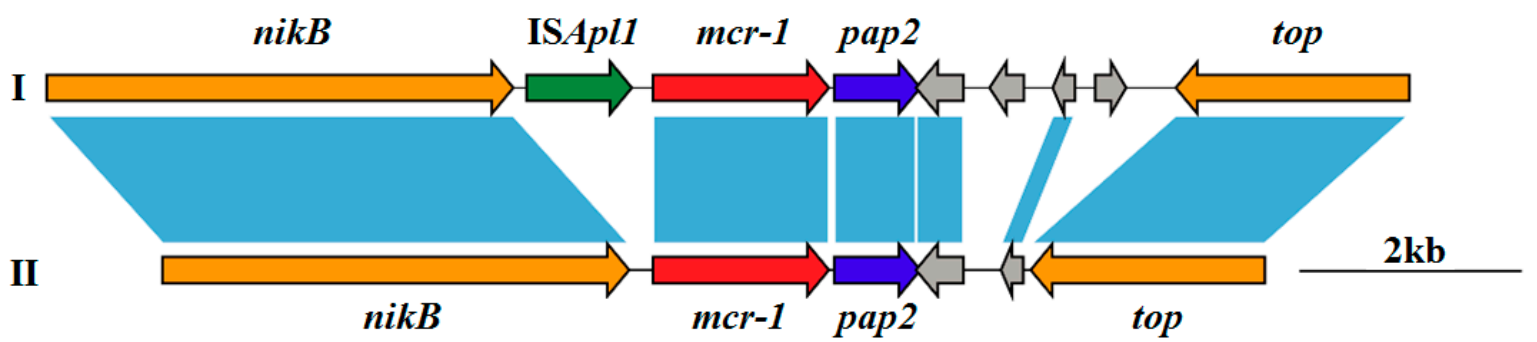

Figure 2. Schematic representation of sequences flanking mor-1 gene. Genes and their corresponding transcriptional orientations are indicated by horizontal broad arrows. (I) One copy of ISApl1 was present beside $m c r-1$; (II) no ISApl1 was present beside $m c r-1$.

\subsection{Plasmids Analysis}

Conjugation experiments and ERIC-PCR analysis results showed that the colistin-resistant phenotype was successfully transferred from donors to azide-resistant E. coli J53 at conjugation frequencies $1.13 \times 10^{-2}-4.35 \times 10^{-7}$ (transconjugants/recipients) (Table 3). The mcr-1 gene was identified in 9 transconjugants. S1-PFGE analysis showed that seven transconjugants carried a single plasmid used for plasmid analysis (Figure 3). Transconjugant harbored a single mor-1-associated plasmid, which ranged in size between 65 and $102 \mathrm{~kb}$ and was assigned to IncI2 $(\mathrm{n}=4)$, IncFII $(\mathrm{n}=2)$ and IncN $(n=1)$ replicon types (Table 3$)$, which have been reported by recent studies to be associated with $m c r-1$ [14,52,53]. Resistant gene bla $a_{\mathrm{CTX}-\mathrm{M}-55}$ was co-transferred with $m c r-1$ on pTA59 plasmid, while no other resistant gene was found to coexist with $m c r-1$ on the other six plasmids. In this study, two IncI2 plasmids were obtained from the same farm, whereas the other five plasmids were respectively recovered from different farms. As a common $\mathrm{mcr}$-disseminator, IncI2 plasmid was identified in isolates from animals, vegetables, and humans $[49,54,55]$. These results suggest that diversified conjugative plasmids, especially IncI2 plasmid, may be the key vectors that mediate the dissemination of the mcr-1 among Enterobacteriaceae [56].
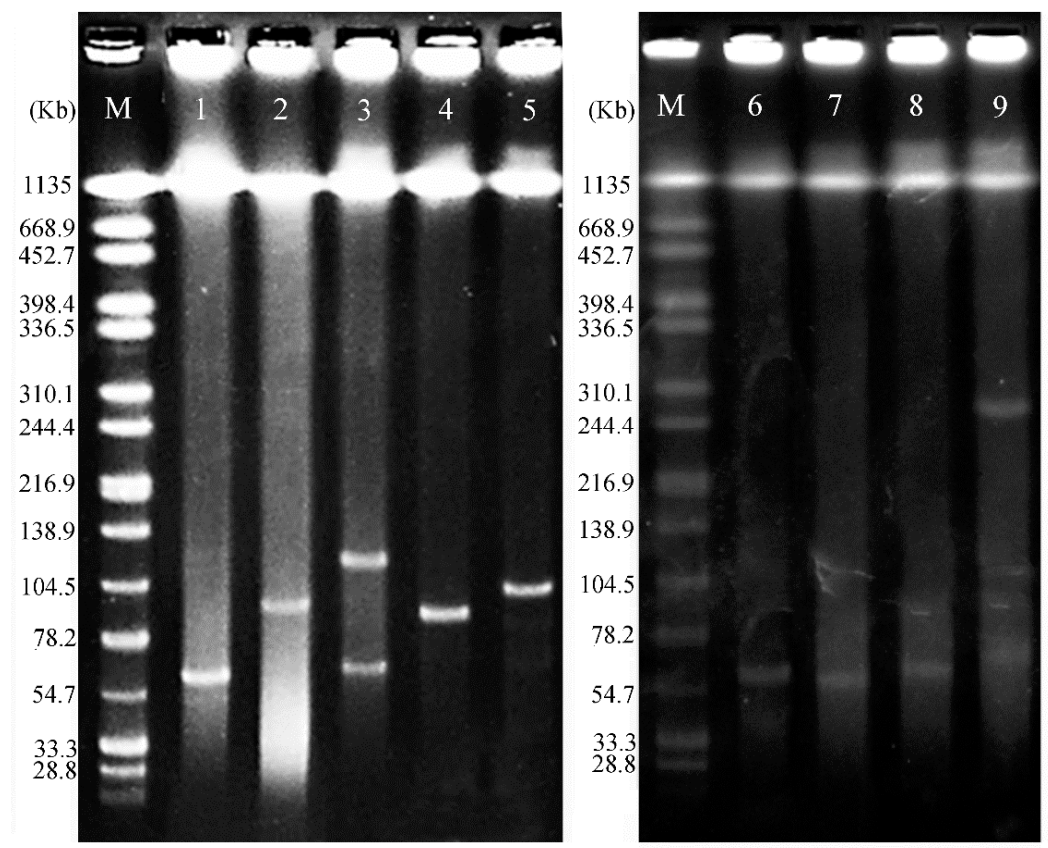

Figure 3. Identification of $m c r-1$ gene-carrying plasmids of transconjugants by S1-PFGE. Lanes 1-9: TA15, TA59, TA103, TA78, TA95, TA9, TA20, TA32, TA114. Lane M, Salmonella serovar Braenderup H9812.

The nucleotide sequence of plasmid pTA9 from strain TA9 has been deposited in GenBank with accession number MN106912. The plasmid size of pTA9 was $66.603 \mathrm{~kb}$, whose GC\% was 41.3\%, 
encoding 72 ORFs (Figure 4). The plasmid pTA9 featured an IncI2 plasmid backbone encoding plasmid transfer, stability, and replication. Two conjugative genes (pil and tra) were predicted on pTA9, which were responsible for the transfer of plasmid between intra- and interspecies bacteria. BLASTn analysis showed that pTA9 was highly similar (the query coverage of $85-97 \%$ and the identities 99\%) with other $m c r-1$-bearing plasmids, such as pMCR1-IncI2 of E. coli (isolated from human in Jiangsu province of China, KU761326.1) [50], pWF-5-19C of Cronobacter sakazakii (isolated from chicken in Shandong province of China, KX505142.1) [57], and the first identified mcr-1-bearing plasmid pHNSHP45 of E. coli (isolated from pig in Shanghai of China, KX505142.1) [14] (Figure 5). TnpA and tnpB were identified in pTA9, pMCR1-IncI2, and pWF-5-19C. In addition, ISApl1 was identified in pTA9, pWF-5-19C, and pHNSHP45. An mor-1-pap2 element was identified in pTA9 and pMCR1-IncI2. This suggests that pTA9-like plasmids may be epidemic plasmids that mediate $m c r-1$ dissemination between distinct host bacteria in China.

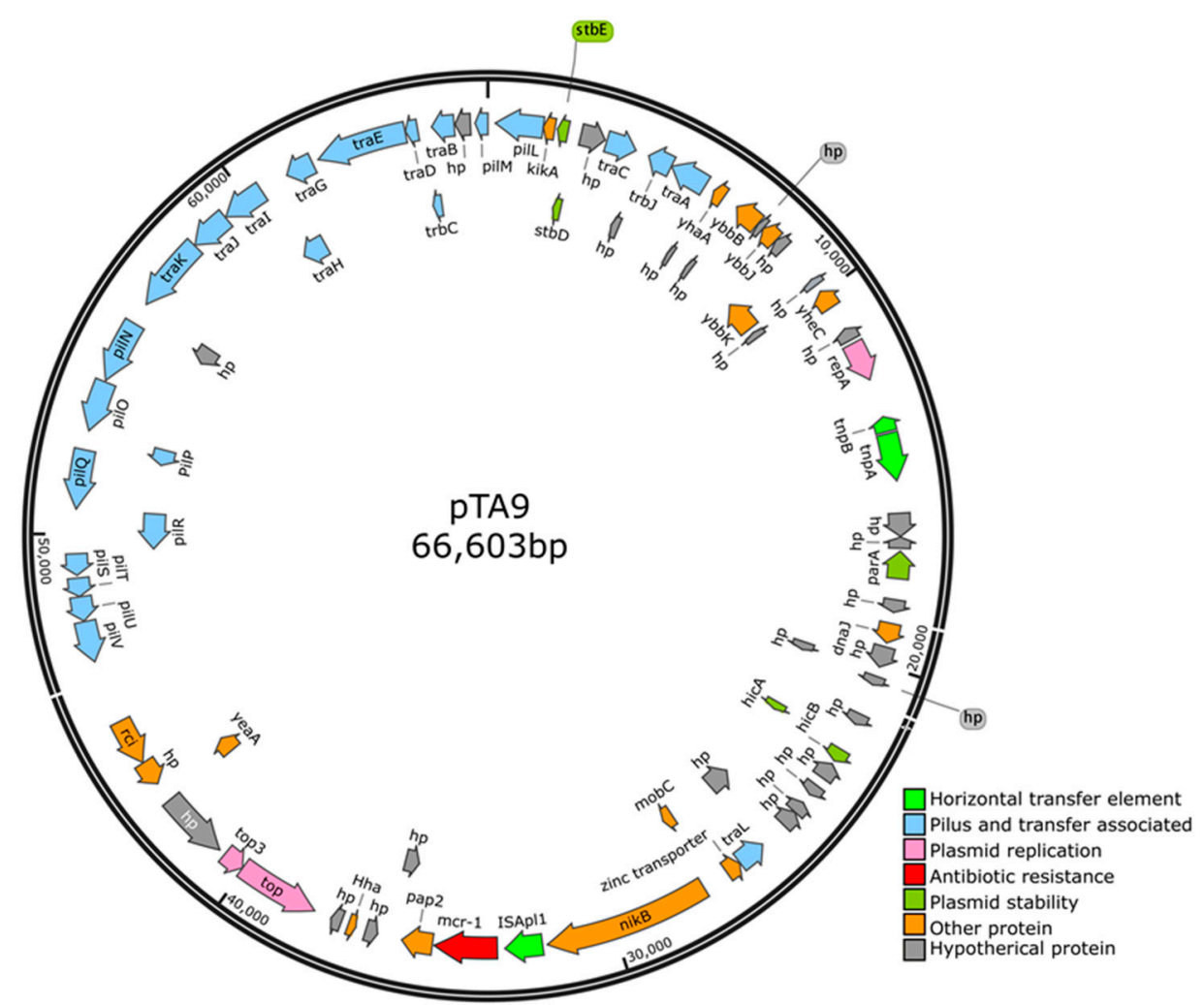

Figure 4. Genomic map of the representative mor-1-carrying plasmid pTA9 from the meat duck gut microbiota.

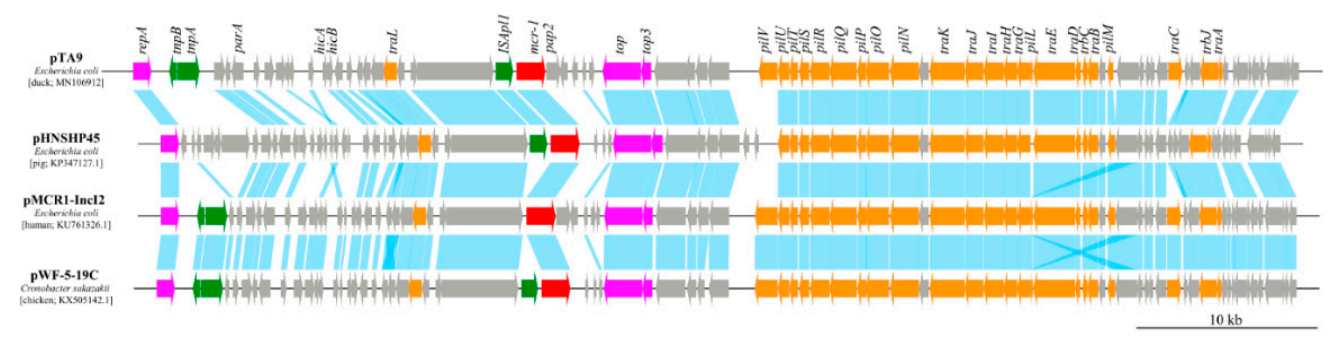

Figure 5. Colinear genome alignments of pTA9 from E. coli TA9 isolated in this study, pHNSHP45 from E. coli SHP45, pMCR1-IncI2 from E. coli SZ02, and pWF-5-19C from Cronobacter sakazakii WF-5-19C.

In this study, pTA9 could be transferred to E. coli J53 isolates in vitro. This suggests that the mcr-1 gene present in gut flora of meat duck can be horizontally transferred by bacterial conjugation among distinct bacterial hosts. Similar scenarios have already been observed in the human intestinal 
flora [58,59]. So $m c r-1$-bearing fecal E. coli in healthy meat ducks could be a source for the transfer of mor-1 through contaminated food to humans.

\section{Conclusions}

This study revealed the carriage rate of $m c r-1$ among fecal $E$. coli isolates obtained from healthy meat ducks in China. PFGE and MLST results indicated that $m c r-1$-bearing E. coli isolates were clonally unrelated. This suggested that the horizontal transfer of plasmids was the main mechanism for the dissemination of $m c r-1$ gene in meat duck farms. The pTA9-like plasmids have been isolated from different bacterial hosts across distinct regions of China, implying that pTA9-like plasmids are likely to be the epidemic $m c r-1$-bearing plasmids that mediate the dissemination of $m c r-1$ in China. Since China is the biggest exporter of meat duck products in the world, the spread of pTA9-like conjugative plasmids across other regions and countries should attract attention. In addition, the mcr-1-bearing E. coli usually carry $b l a_{\mathrm{CTX}-\mathrm{M}}$ and $f l o R$, conferring resistance to cephalosporins and florfenicol, which made coselection possible when these drugs were used. Restrictive/rational use of antibiotics in animal husbandry, especially in food animals in China may help to limit the spread of $m c r-1$ gene.

Supplementary Materials: The following are available online at http://www.mdpi.com/2076-2615/10/8/1299/s1, Table S1: The primers used in this study.

Author Contributions: Conceptualization, R.Z. and S.J.; data curation, F.L. and J.W.; formal analysis, J.L., Y.Z., and Z.X.; investigation, F.L., R.Z., Y.Y., and H.L.; methodology, F.L., and Y.Y.; resources, F.L., and S.J.; writing —original draft preparation, F.L.; writing—review and editing, P.L. and S.J.; supervision, S.J.; project administration, S.J.; funding acquisition, S.J. All authors have read and agreed to the published version of the manuscript.

Funding: This work was funded by grants from Shandong Modern Agricultural Technology \& Industry System, China (SDAIT-11-15) and Funds of Shandong "Double Tops" Program, China (SYL2017YSTD11).

Conflicts of Interest: The authors declare no conflict of interest.

\section{References}

1. Dziva, F.; Hauser, H.; Connor, T.R.; van Diemen, P.M.; Prescott, G.; Langridge, G.C.; Eckert, S.; Chaudhuri, R.R.; Ewers, C.; Mellata, M.; et al. Sequencing and functional annotation of avian pathogenic Escherichia coli serogroup $\mathrm{O} 78$ strains reveal the evolution of E. coli lineages pathogenic for poultry via distinct mechanisms. Infect. Immun. 2013, 81, 838-849. [CrossRef]

2. Ewers, C.; Antao, E.M.; Diehl, I.; Philipp, H.C.; Wieler, L.H. Intestine and environment of the chicken as reservoirs for extraintestinal pathogenic Escherichia coli strains with zoonotic potential. Appl. Environ. Microbiol. 2009, 75, 184-192. [CrossRef] [PubMed]

3. Mellata, M. Human and avian extraintestinal pathogenic Escherichia coli: Infections, zoonotic risks, and antibiotic resistance trends. Foodborne Pathog. Dis. 2013, 10, 916-932. [CrossRef] [PubMed]

4. Falagas, M.E.; Kasiakou, S.K. Colistin: The revival of polymyxins for the management of multidrug-resistant gram-negative bacterial infections. Clin. Infect. Dis. 2005, 40, 1333-1341. [CrossRef]

5. Carattoli, A.; Villa, L.; Feudi, C.; Curcio, L.; Orsini, S.; Luppi, A.; Pezzotti, G.; Magistrali, C.F. Novel plasmid-mediated colistin resistance mcr-4 gene in Salmonella and Escherichia coli, Italy 2013, Spain and Belgium, 2015 to 2016. Euro Surveill. 2017, 22, 30589. [CrossRef]

6. Carroll, L.M.; Gaballa, A.; Guldimann, C.; Sullivan, G.; Henderson, L.O.; Wiedmann, M. Identification of novel mobilized colistin resistance gene mcr-9 in a multidrug-resistant, colistin-susceptible Salmonella enterica serotype Typhimurium isolate. MBio 2019, 10, e00853-19. [CrossRef]

7. Wang, C.; Feng, Y.; Liu, L.; Wei, L.; Kang, M.; Zong, Z. Identification of novel mobile colistin resistance gene mcr-10. Emerg. Microbes Infect. 2020, 9, 508-516. [CrossRef] [PubMed]

8. Schwarz, S.; Johnson, A.P. Transferable resistance to colistin: A new but old threat. J. Antimicrob. Chemother. 2016, 71, 2066-2070. [CrossRef]

9. Chen, K.C.; Chan, E.W.; Xie, M.M.; Ye, L.W.; Dong, N.; Chen, S. Widespread distribution of mcr-1-bearing bacteria in the ecosystem, 2015 to 2016. Eurosurveillance 2017, 22, 17-00206. [CrossRef] 
10. Hu, Y.F.; Liu, F.; Lin, I.Y.; Gao, G.F.; Zhu, B.L. Dissemination of the mcr-1 colistin resistance gene. Lancet Infect. Dis. 2016, 16, 146-147. [CrossRef]

11. Wang, Q.J.; Sun, J.; Li, J.; Ding, Y.F.; Li, X.P.; Lin, J.X.; Hassan, B.; Feng, Y.J. Expanding landscapes of the diversified mcr-1-bearing plasmid reservoirs. Microbiome 2017, 5, 70. [CrossRef] [PubMed]

12. Salyers, A.A.; Gupta, A.; Wang, Y.P. Human intestinal bacteria as reservoirs for antibiotic resistance genes. Trends Microbiol. 2004, 12, 412-416. [CrossRef] [PubMed]

13. Skurnik, D.; Clermont, O.; Guillard, T.; Launay, A.; Danilchanka, O.; Pons, S.; Diancourt, L.; Lebreton, F.; Kadlec, K.; Roux, D.; et al. Emergence of antimicrobial-resistant Escherichia coli of animal origin spreading in humans. Mol. Biol. Evol. 2016, 33, 898-914. [CrossRef] [PubMed]

14. Liu, Y.Y.; Wang, Y.; Walsh, T.R.; Yi, L.X.; Zhang, R.; Spencer, J.; Doi, Y.; Tian, G.B.; Dong, B.L.; Huang, X.H.; et al. Emergence of plasmid-mediated colistin resistance mechanism MCR-1 in animals and human beings in China: A microbiological and molecular biological study. Lancet Infect. Dis. 2016, 16, 161-168. [CrossRef]

15. Tang, Y.; Diao, Y.X.; Gao, X.H.; Yu, C.M.; Chen, H.; Zhang, D.B. Analysis of the complete genome of Tembusu virus, a flavivirus isolated from ducks in China. Transbound. Emerg. Dis. 2012, 59, 336-343. [CrossRef]

16. Li, Z.; Wang, X.; Zhang, R.; Chen, J.; Xia, L.; Lin, S.; Xie, Z.; Jiang, S. Evidence of possible vertical transmission of duck circovirus. Vet. Microbiol. 2014, 174, 229-232. [CrossRef]

17. Li, P.; Lin, S.; Zhang, R.; Chen, J.; Sun, D.; Lan, J.; Song, S.; Xie, Z.; Jiang, S. Isolation and characterization of novel goose parvovirus-related virus reveal the evolution of waterfowl parvovirus. Transbound. Emerg. Dis. 2018, 65, e284-e295. [CrossRef]

18. Zhang, R.; Chen, J.; Zhang, J.; Yang, Y.; Li, P.; Lan, J.; Xie, Z.; Jiang, S. Novel duck hepatitis A virus type 1 isolates from adult ducks showing egg drop syndrome. Vet. Microbiol. 2018, 221, 33-37. [CrossRef]

19. Lan, J.; Zhang, R.; Li, P.; Chen, J.; Xie, Z.; Jiang, S. Identification of a type-specific epitope in the ORF2 protein of duck astrovirus type 1. Animals 2019, 9, 1069. [CrossRef]

20. Yang, F.F.; Sun, Y.N.; Li, J.X.; Wang, H.; Zhao, M.J.; Su, J.; Zhang, Z.J.; Liu, H.J.; Jiang, S.J. Detection of Aminoglycoside resistance genes in Riemerella anatipestifer isolated from ducks. Vet. Microbiol. 2012, 158, 451-452. [CrossRef]

21. Liu, C.Y.; Diao, Y.J.; Wang, D.X.; Chen, H.; Tang, Y.; Diao, Y.X. Duck viral infection escalated the incidence of avian pathogenic Escherichia coli in China. Transbound. Emerg. Dis. 2019, 66, 929-938. [CrossRef] [PubMed]

22. Zhang, J.; Chen, L.; Wang, J.; Yassin, A.K.; Butaye, P.; Kelly, P.; Gong, J.; Guo, W.; Li, J.; Li, M.; et al. Molecular detection of colistin resistance genes (mcr-1, $m c r-2$ and $m c r-3)$ in nasal/oropharyngeal and anal/cloacal swabs from pigs and poultry. Sci. Rep. 2018, 8, 3705. [CrossRef] [PubMed]

23. Yang, R.S.; Feng, Y.; Lv, X.Y.; Duan, J.H.; Chen, J.; Fang, L.X.; Xia, J.; Liao, X.P.; Sun, J.; Liu, Y.H. Emergence of NDM-5- and MCR-1-Producing Escherichia coli Clones ST648 and ST156 from a Single Muscovy Duck (Cairina moschata). Antimicrob. Agents Chemother. 2016, 60, 6899-6902. [CrossRef] [PubMed]

24. Yassin, A.K.; Zhang, J.; Wang, J.; Chen, L.; Kelly, P.; Butaye, P.; Lu, G.; Gong, J.; Li, M.; Wei, L.; et al. Identification and characterization of mcr mediated colistin resistance in extraintestinal Escherichia coli from poultry and livestock in China. FEMS Microbiol. Lett. 2017, 364, 10. [CrossRef] [PubMed]

25. Clinical and Laboratory Strandards Institute. Performance Standands for Antimicrobial Susceptibility Testing; Twenty-Fifth Information Supplement M100-S25; Clinical and Laboratory Strandards Institute: Wayne, PA, USA, 2015.

26. Clinical and Laboratory Strandards Institute. Performance Standards for Antimicrobial Disk and Dilution Susceptibility Tests for Bacteria Isolated from Animals, 3rd ed.; CLSI Supplement VET01-S; Clinical and Laboratory Strandards Institute: Wayne, PA, USA, 2015.

27. European Committee on Antimicrobial Susceptibility Testing (EUCAST). Breakpoint Tables for Interpretation of MICs and Zone Diameters: Version 6.0. 2016. Available online: https://www.eucast.org/ast_of_bacteria/ previous_versions_of_documents/ (accessed on 29 July 2020).

28. Johnson, J.R.; Stell, A.L. Extended virulence genotypes of Escherichia coli strains from patients with urosepsis in relation to phylogeny and host compromise. J. Infect. Dis. 2000, 181, 261-272. [CrossRef]

29. Stürenburg, E.; Kühn, A.; Mack, D.; Laufs, R. A novel extended-spectrum beta-lactamase CTX-M-23 with a P167T substitution in the active-site omega loop associated with ceftazidime resistance. J. Antimicrob. Chemother. 2004, 54, 406-409. [CrossRef] 
30. Maynard, C.; Fairbrother, J.M.; Bekal, S.; Sanschagrin, F.; Levesque, R.C.; Brousseau, R.; Masson, L.; Larivière, S.; Harel, J. Antimicrobial resistance genes in enterotoxigenic Escherichia coli O149:K91 isolates obtained over a 23-year period from pigs. Antimicrob. Agents Chemother. 2003, 47, 3214-3221. [CrossRef]

31. Hou, J.X.; Huang, X.H.; Deng, Y.T.; He, L.Y.; Yang, T.; Zeng, Z.L.; Chen, Z.; Liu, J.H. Dissemination of the fosfomycin resistance gene fosA3 with CTX-M $\beta$-lactamase genes and $\mathrm{rmtB}$ carried on IncFII plasmids among Escherichia coli isolates from pets in China. Antimicrob. Agents Chemother. 2012, 56, 2135-2138. [CrossRef]

32. Johnson, J.R.; Murray, A.C.; Gajewski, A.; Sullivan, M.; Snippes, P.; Kuskowski, M.A.; Smith, K.E. Isolation and molecular characterization of nalidixic acid-resistant extraintestinal pathogenic Escherichia coli from retail chicken products. Antimicrob. Agents Chemother. 2003, 47, 2161-2168. [CrossRef]

33. Gautom, R.K. Rapid pulsed-field gel electrophoresis protocol for typing of Escherichia coli O157:H7 and other gram-negative organisms in 1 day. J. Clin. Microbiol. 1997, 35, 2977-2980. [CrossRef]

34. Pavel, A.B.; Vasile, C.I. PyElph-a software tool for gel images analysis and phylogenetics. BMC Bioinf. 2012, 13, 9. [CrossRef] [PubMed]

35. Tartof, S.Y.; Solberg, O.D.; Manges, A.R.; Riley, L.W. Analysis of a uropathogenic Escherichia coli clonal group by multilocus sequence typing. J. Clin. Microbiol. 2005, 43, 5860-5864. [CrossRef] [PubMed]

36. Clermont, O.; Bonacorsi, S.; Bingen, E. Rapid and simple determination of the Escherichia coli phylogenetic group. Appl. Environ. Microbiol. 2000, 66, 4555-4558. [CrossRef]

37. Borgia, S.; Lastovetska, O.; Richardson, D.; Eshaghi, A.; Xiong, J.; Chung, C.; Baqi, M.; McGeer, A.; Ricci, G.; Sawicki, R.; et al. Outbreak of carbapenem-resistant Enterobacteriaceae containing blaNDM-1, Ontario, Canada. Clin. Infect. Dis. 2012, 55, e109-e117. [CrossRef] [PubMed]

38. Versalovic, J.; Koeuth, T.; Lupski, J.R. Distribution of repetitive DNA sequences in eubacteria and application to fingerprinting of bacterial genomes. Nucleic Acids Res. 1991, 19, 6823-6831. [CrossRef]

39. Carattoli, A.; Bertini, A.; Villa, L.; Falbo, V.; Hopkins, K.L.; Threlfall, E.J. Identification of plasmids by PCR-based replicon typing. J. Microbiol. Methods. 2005, 63, 219-228. [CrossRef] [PubMed]

40. Wang, Q.; Li, Z.; Lin, J.; Wang, X.; Deng, X.; Feng, Y. Complex dissemination of the diversified mcr-1-harbouring plasmids in Escherichia coli of different sequence types. Oncotarget 2016, 7, 82112-82122. [CrossRef]

41. Huang, X.; Yu, L.; Chen, X.; Zhi, C.; Yao, X.; Liu, Y.; Wu, S.; Guo, Z.; Yi, L.; Zeng, Z.; et al. High prevalence of colistin resistance and mcr-1 gene in Escherichia coli isolated from food animals in China. Front. Microbiol. 2017, 8, 562. [CrossRef]

42. Cui, M.Q.; Zhang, J.F.; Zhang, C.P.; Li, R.C.; Wai-Chi Chan, E.; Wu, C.B.; Wu, C.M.; Chen, S. Distinct mechanisms of acquisition of mcr-1-bearing plasmid by Salmonella strains recovered from animals and food samples. Sci. Rep. 2017, 7, 13199. [CrossRef]

43. Haenni, M.; Poirel, L.; Kieffer, N.; Châtre, P.; Saras, E.; Métayer, V.; Dumoulin, R.; Nordmann, P.; Madec, J.Y. Co-Occurrence of extended spectrum $\beta$ lactamase and MCR-1 encoding genes on plasmids. Lancet Infect. Dis. 2016, 16, 281-282. [CrossRef]

44. Yang, F.; Shen, C.; Zheng, X.B.; Liu, Y.; El-Sayed Ahmed, M.A.E.; Zhao, Z.H.; Liao, K.; Shi, Y.L.; Guo, X.; Zhong, R.X.; et al. Plasmid-Mediated colistin resistance gene mcr-1 in Escherichia coli and Klebsiella pneumoniae isolated from market retail fruits in Guangzhou, China. Infect. Drug Resist. 2019, 12, 385-389. [CrossRef] [PubMed]

45. Obeng, A.S.; Rickard, H.; Ndi, O.; Sexton, M.; Barton, M. Antibiotic resistance, phylogenetic grouping and virulence potential of Escherichia coli isolated from the faeces of intensively farmed and free range poultry. Vet. Microbiol. 2012, 154, 305-315. [CrossRef] [PubMed]

46. Mitchell, N.M.; Johnson, J.R.; Johnston, B.; Curtiss, R., 3rd; Mellata, M. Zoonotic potential of Escherichia coli isolates from retail chicken meat products and eggs. Appl. Environ. Microbiol. 2015, 81, 1177-1187. [CrossRef] [PubMed]

47. Liu, B.T.; Li, X.Y.; Zhang, Q.D.; Shan, H.; Zou, M.; Song, F.J. Colistin-Resistant mcr-positive Enterobacteriaceae in fresh vegetables, an increasing infectious threat in China. Int. J. Antimicrob. Agents. 2019, 54, 89-94. [CrossRef]

48. Shen, Y.B.; Wu, Z.W.; Wang, Y.; Zhang, R.; Zhou, H.W.; Wang, S.L.; Lei, L.; Li, M.; Cai, J.C.; Tyrrell, J.; et al. Heterogeneous and flexible transmission of mcr-1 in hospital-associated Escherichia coli. MBio 2018, 9, e00943-18. [CrossRef] 
49. Schaufler, K.; Semmler, T.; Wieler, L.H.; Wöhrmann, M.; Baddam, R.; Ahmed, N.; Müller, K.; Kola, A.; Fruth, A.; Ewers, C.; et al. Clonal spread and interspecies transmission of clinically relevant ESBL-producing Escherichia coli of ST410-another successful pandemic clone? FEMS Microbiol. Ecol. 2016, 92, fiv155. [CrossRef]

50. Li, A.Q.; Yang, Y.; Miao, M.H.; Chavda, K.D.; Mediavilla, J.R.; Xie, X.F.; Feng, P.; Tang, Y.W.; Kreiswirth, B.N.; Chen, L.; et al. Complete sequences of mcr-1-harboring plasmids from extended-spectrum beta-lactamase and carbapenemase-producing Enterobacteriaceae. Antimicrob. Agents Chmother. 2016, 60, 4351-4354. [CrossRef]

51. Snesrud, E.; He, S.; Chandler, M.; Dekker, J.P.; Hickman, A.B.; McGann, P.; Dyda, F. A model for transposition of the colistin resistance gene mcr-1 by ISApl1. Antimicrob. Agents Chmother. 2016, 60, 6973-6976. [CrossRef]

52. Xavier, B.B.; Lammens, C.; Butaye, P.; Goossens, H.; Malhotra-Kumar, S. Complete sequence of an IncFII plasmid harbouring the colistin resistance gene mcr-1 isolated from Belgian pig farms. J. Antimicrob. Chemother. 2016, 71, 2342-2344. [CrossRef]

53. Shafiq, M.; Huang, J.H.; Ur Rahman, S.; Shah, J.M.; Chen, L.; Gao, Y.; Wang, M.L.; Wang, L.P. High incidence of multidrug-resistant Escherichia coli coharboring mcr-1 and bla Resist. 2019, 12, 2135-2149. [CrossRef]

54. Kawahara, R.; Khong, D.T.; Le, H.V.; Phan, Q.N.; Nguyen, T.N.; Yamaguchi, T.; Kumeda, Y.; Yamamoto, Y. Prevalence of mcr-1 among cefotaxime-resistant commensal Escherichia coli in residents of Vietnam. Infect. Drug Resist. 2019, 12, 3317-3325. [CrossRef] [PubMed]

55. Sun, J.; Li, X.P.; Yang, R.S.; Fang, L.X.; Huo, W.; Li, S.M.; Jiang, P.; Liao, X.P.; Liu, Y.H. Complete nucleotide sequence of an IncI2 plasmid coharboring bla ${ }_{\mathrm{CTX}-\mathrm{M}-55}$ and mcr-1. Antimicrob. Agents Chemother. 2016, 60, 5014-5017. [CrossRef] [PubMed]

56. Tijet, N.; Faccone, D.; Rapoport, M.; Seah, C.; Pasterán, F.; Ceriana, P.; Albornoz, E.; Corso, A.; Petroni, A.; Melano, R.G. Molecular characteristics of mcr-1-carrying plasmids and new mcr-1 variant recovered from polyclonal clinical Escherichia coli from Argentina and Canada. PLoS ONE 2017, 12, e0180347. [CrossRef] [PubMed]

57. Liu, B.T.; Song, F.J.; Zou, M.; Hao, Z.H.; Shan, H. Emergence of colistin resistance gene mcr-1 in Cronobacter sakazakii producing NDM-9 and in Escherichia coli from the Same Animal. Antimicrob. Agents Chemother. 2017, 61, e01444-16. [CrossRef] [PubMed]

58. Ye, H.Y.; Li, Y.H.; Li, Z.C.; Gao, R.S.; Zhang, H.; Wen, R.H.; Gao, G.F.; Hu, Q.H.; Feng, Y.J. Diversified mcr-1-harbouring plasmid reservoirs confer resistance to colistin in human gut microbiota. mBio. 2016, 7, e00177. [CrossRef] [PubMed]

59. Zhang, H.M.; Seward, C.H.; Wu, Z.W.; Ye, H.Y.; Feng, Y.J. Genomic insights into the ESBL and MCR-1-producing ST648 Escherichia coli with multi-drug resistance. Sci. Bull. 2016, 61, 875-878. [CrossRef] 